\title{
COVID-19 Infection and its Relation to Preterm Delivery in Pregnant Women
}

\author{
Mohammed Ismael Dawood ${ }^{1}$, Rasha Shakir ${ }^{2}$, Mohanned H. Alwan ${ }^{3}$ \\ ${ }^{1,2,3}$ Lecturer, College of Medicine, University of Al-Fallujah, Iraq
}

\begin{abstract}
The study aims to find the relationship between COVID-19 virus infections and early births in women infected with this virus in of Al-Fallujah city. The prospective study was conducted in Al-Fallujah city during the period between February 1, 2020, and September 1, 2020, at Al-Fallujah Teaching Hospital. Through the study, 100 pregnant women were received, complaining of Covid-19 infections, which were diagnosed in Al-Fallujah, and now Real Time PCR was confirmed through nasopharyngeal swabs that were taken from Al-Fallujah Teaching Hospital. The study also included measuring the level of blood pressure, sugar andC-RP in those women during the fifth to eight week, where we were infected, and then in the 12th week of pregnancy took place, where communication was made, and a level was measured, and as a result, these women whocompleted the period with a pre-term labor, miscarriagebefore the $24^{\text {th }}$ week of pregnancy or those completed the period with successful pregnancy. In this study, 33\% of COVID-19 pregnant women were within the age group 24-30 years followed by 30\% in the age group 31-38 year. In this study, $10 \%$ of COVID-19 pregnant women suffer from hypertension, $13 \%$ were with Diabetes, $35 \%$ with UTI while $70 \%$ were suffered from fever.When reaching $24^{\text {th }}$ week of pregnancy, and as shown in Table 3 . The study showed that $40 \%$ COVID-19 pregnant women experienced completed the period with a pre-term labor, $10 \%$ was with miscarriagebefore the $24^{\text {th }}$ week of pregnancy, while $50 \%$ of them completed the period continued the pregnancy. In this study, $82.5 \%$ of COVID-19 pregnant women with preterm labor were suffered previously from fever comparing with 55\% of COVID-19 pregnant women without preterm labor. The study showed the highest mean of C-reactive protein was present COVID-19 pregnant women with preterm labor $(22.5 \pm 2.14$ $\mathrm{mg} / \mathrm{ml})$, fan lowest mean was in women who without preterm labor $(14.6 \pm 2.11 \mathrm{mg} / \mathrm{ml})(\mathrm{P}<0.01)$.
\end{abstract}

Conclusions: The study showed a significant relation ofCOVID-19 infection with pregnant women who pre-term labor especially who have high body temperature.

Keywords: COVID-19; Preterm delivery; pregnant women; C-reactive protein.

\section{Introduction}

New Corona virus infections are considered one of the most deadly diseases in society these days, especially people who kill countries affected by the virus, and recent studies have indicated that there is a strong relationship between the high level of infection with Corona virus 19 failure to respect global health laws and follow the instructions that my son and use

\section{Corresponding Author:}

Mohammed Ismael Dawood

Lecturer, College of Medicine, University of AlFallujah, Iraq sterilizer and wash treatment With among people ${ }^{(1)}$. It is worth noting that one of the diseases associated with Virus Corona is chest infections and coughing that exacerbate cases of Covid 19 in society ${ }^{(2)}$. As the Covid 19 virus is considered one of the most important diseases that have appeared in society and that do not affect all ages and genders, regardless of their living condition, but the role of immunity has a great role in expelling the virus or keeping it in a state that can multiply and affect a person's health ${ }^{(3)}$. There is no doubt that Corona injuries may lead to medicine for people, as the study indicated that Corona injuries are major problems, problems of pregnant women, which deal with miscarriage or early childbirth associated with high blood sugar or high blood 
pressure $^{(4,5)}$. High temperatures in people with Covid virus 19 are tormented by one of the most important causes of respiratory disorder due to the high level of cytokinins like Interleukin 1 and Interleukin 6 and the C-reactive protein, which adversely affects the health condition through the cytokinin A storm in infected people ${ }^{(6,7)}$. TWhich may lead to health problems, especially in pregnant women, which may lead to abortion or premature labor in pregnant women ${ }^{(8)}$. The study aims to find the relationship between Covid 19 virus infections and early births in women infected with this virus in of Al-Fallujah city.

\section{Materials and Method}

The study was conducted in the city of Al-Fallujah during the period between February 1, 2020, and September 1, 2020, at Al-Fallujah Teaching Hospital. Through the study, 100 pregnant women were received, complaining of Covid-19 infections, which were diagnosed in Al-Fallujah, and now Real Time PCR was confirmed through nasopharyngeal swabs that were taken from Al-Fallujah Teaching Hospital. The study also included measuring the level of blood pressure, sugar andC-RP in those women during the fifth to eight week, where we were infected, and then in the 12th week of pregnancy took place, where communication was made, and a level was measured, and as a result, these women who completed the period with a pre-term labor, miscarriagebefore the $24^{\text {th }}$ week of pregnancy or those completed the period with successful pregnancy

\section{Results}

In this study, $33 \%$ of COVID-19 pregnant women were within the age group 24-30 years followed by $30 \%$ in the age group 31-38 year(Table 1).

Table 1: Age characteristics of COVID-19 pregnant women

\begin{tabular}{|c|c|}
\hline Age Groups (Years) & No (\%) \\
\hline $17-23$ & 20 \\
\hline $24-30$ & 33 \\
\hline $31-38$ & 30 \\
\hline $39-45$ & 17 \\
\hline Total & $\mathbf{1 0 0}$ \\
\hline
\end{tabular}

In this study, $10 \%$ of COVID-19 pregnant women suffer from hypertension, $13 \%$ were with Diabetes, $35 \%$ with UTI while $70 \%$ were suffered from fever.(Table 2).

Table 2: Distribution of COVID-19 pregnant women according to different situations.

\begin{tabular}{|l|c|c|c|c|}
\hline \multirow{2}{*}{ Variables } & \multicolumn{2}{|c|}{ Present } & \multicolumn{2}{c|}{ Absent } \\
\cline { 2 - 5 } & No. & \% & No. & \% \\
\hline Hypertension & 10 & 10 & 90 & 90 \\
\hline Diabetes & 13 & 13 & 87 & 87 \\
\hline UTI & 35 & 35 & 65 & 65 \\
\hline Fever & 70 & 70 & 30 & 30 \\
\hline
\end{tabular}

When reaching $24^{\text {th }}$ week of pregnancy, and as shown in Table 3. The study showed that 40\% COVID-19 pregnant women experienced completed the period with a pre-term labor, $10 \%$ was with miscarriagebefore the $24^{\text {th }}$ week of pregnancy, while $50 \%$ of them completed the period continued the pregnancy.

In this study, $82.5 \%$ of COVID-19 pregnant women with preterm labor were suffered previously from fever comparing with $55 \%$ of COVID-19 pregnant women without preterm labor, Table 4.
Table 3: Distribution of sCOVID-19 pregnant women according to pregnancy outcomes

\begin{tabular}{|l|c|c|}
\hline \multirow{2}{*}{ Pregnancy outcomes } & \multicolumn{2}{|c|}{ Cases } \\
\cline { 2 - 3 } & No. & \% \\
\hline Miscarriage & 10 & 10 \\
\hline Preterm labor & 40 & 40 \\
\hline Continued pregnancy & 50 & 50 \\
\hline Total & 35 & 100 \\
\hline
\end{tabular}

$\mathrm{X}^{2}: 7.55$ P. value : 0.01 
Table 4: Relation of Fever with preterm labor among VOVID-19 pregnant women

\begin{tabular}{|l|c|c|c|c|c|c|}
\hline \multirow{2}{*}{ Preterm labor } & \multicolumn{3}{|c|}{ Fever $(>\mathbf{3 8} \mathbf{C})$ at 5-8 } & \multicolumn{2}{c|}{ Total } \\
\cline { 2 - 6 } & \multicolumn{2}{|c|}{ Present } & \multicolumn{2}{c|}{ Absent } & \multirow{2}{*}{ No. } & \multirow{2}{*}{$\%$} \\
\cline { 2 - 7 } & No. & $\mathbf{\%}$ & No. & $\mathbf{\%}$ & & 10 \\
\hline Yes & 37 & 82.5 & 3 & 10 & 60 & 100 \\
\hline No & 33 & 55 & 27 & 45 & 400 \\
\hline
\end{tabular}

$\mathrm{P}<0.001$

The study showed the highest mean of C-reactive protein was present COVID-19 pregnant women with preterm labor $(22.5 \pm 2.14 \mathrm{mg} / \mathrm{ml})$, fan lowest mean was in women who without preterm labor $(14.6 \pm 2.11 \mathrm{mg} / \mathrm{ml})$ $(\mathrm{P}<0.01)$, as shown in Table 5 .

Table 5: Relation of CRP level with preterm labor among VOVID-19 pregnant women

\begin{tabular}{|l|c|c|}
\hline \multirow{2}{*}{ Preterm labor } & \multicolumn{2}{|c|}{ C-Reactive protein $(\mathbf{m g} / \mathbf{m l})$} \\
\cline { 2 - 3 } & Mean & SD \\
\hline Yes (n:40) & 22.5 & 2.41 \\
\hline No (n:60) & 14.6 & 2.11 \\
\hline
\end{tabular}

$\mathrm{P}<0.001$

\section{Discussion}

In this study, 33\% of COVID-19 pregnant women were within the age group 24-30 years followed by $30 \%$ in the age group 31-38 year(Table 1).Consistent with what our study has reached, many studies also found that most of the ages affected by the Corona virus here are pregnant women were less than 30 years old ${ }^{(6,7)}$. This age period is considered the most vulnerable to premature birth, as was proven in previous studies ${ }^{(8,9)}$. In this study, $10 \%$ of COVID-19 pregnant women suffer from hypertension, $13 \%$ were with Diabetes, $35 \%$ with UTI while $70 \%$ were suffered from fever.(Table 2). There is no doubt that among the most important problems that pregnant women face is high blood level, high level of diabetes, and also UTI ${ }^{(1)}$. Where previously conducted studies mentioned that most women with urinary tract infection are pregnant, and as the study indicated that most pregnant women with Coronavirus suffer from high levels of temperature due to infection with the Corona virus, which leads to high temperatures, coughing, shortness of breath, muscle and bone pain ${ }^{(10,11)}$. When reaching $24^{\text {th }}$ week of pregnancy, and as shown in Table 3. The study showed that $40 \%$ COVID-19 pregnant women experienced completed the period with a pre-term labor, $10 \%$ was with miscarriagebefore the $24^{\text {th }}$ week of pregnancy, while $50 \%$ of them completed the period continued the pregnancy. On the level of similarities, recent studies conducted this year indicated that most of the women infected with the Coronavirus, who were there during pregnancy, had suffered from pregnancy specialization disorders, including premature birth and abortion, as well as the problem of premature birth at least $40 \%$ of these women ${ }^{(12,13)}$. A study conducted in Wuhan stated that women infected with Coronavirus are more likely to have early labor due to the worsening of the health condition in pregnant womenand due to elevated levels of cytokines that affect the baby health ${ }^{(2)}$. In this study, $82.5 \%$ of COVID-19 pregnant women with preterm labor were suffered previously from fever comparing with 55\% of COVID-19 pregnant women without preterm labor, Table 4.From previous studies and from the information accumulated by everyone that repeated infections with the COVID-19 include high temperatures in infected people as well as other respiratory symptoms. They complain of high temperatures compared to women who are not enough in the asymptomatic infections ${ }^{(14,15)}$. Other scientists have instructed similar studies on high temperatures in patients with Covid 19 virus that may result from an elevated level of interleukin-16, CRP and TNF alpha $(16,17)$. The study showed the highest mean of C-reactive protein was present COVID-19 pregnant women with preterm labor $(22.5 \pm 2.14 \mathrm{mg} / \mathrm{ml})$, fan lowest mean was in women who without preterm labor $(14.6 \pm 2.11 \mathrm{mg} / \mathrm{ml})$ $(\mathrm{P}<0.01)$, as shown in Table 5. There is no doubt that the level of the reactive protein, a type that is high in infections and viral on the limit of the reactive protein, the type of disease of people with Covid 19 virus is a sign of the task of secondary bacterial infections in the respiratory, upper and lower system of people, the virus, especially since the infected are pregnant women, and pregnant women are known to suffer Those who have 
it and the bacteria that infect them as a result these circumstances ${ }^{(18)}$.

\section{Conclusions}

The study showed a significant relation ofCOVID-19 infection with pregnant women who pre-term labor especially who have high body temperature.

\section{Conflict of Interest: None}

Source of Findings: None

Ethical Clearance: None

\section{References}

1. Zhang L, Jiang Y, Wei M, Cheng BH, Zhou XC, Li J, Tian JH, Dong L, Hu RH. Analysis of the pregnancy outcomes in pregnant women with COVID-19 in Hubei Province. Zhonghua fu chanke za zhi. 2020; 7;55:E009.

2. World Health Organization. Regional Officefor Eastern Mediterranean: MERS situation update. Geneva: World Health Organization; 2020..

3. Huang C,Wang Y, Li X, et al. Clinical features ofpatients infected with 2019 novel coronavirus inWuhan, China [published correction appears inLancet 2020 Jan 30]. Lancet 2020;395:497-506.

4. Coronavirus disease 2019 (COVID-2019). Situation report 54. Geneva: World Health Organization;2020.

5. Wang $\mathrm{D}, \mathrm{Hu} \mathrm{B}, \mathrm{Hu}$ C, et al. Clinical characteristicsof 138 hospitalized patients with 2019novel coronavirus-infected pneumonia inWuhan, China, JAMA 2020:e201585.

6. Chen YH, Keller J, Wang IT, Lin CC, Lin HC.Pneumonia and pregnancy outcomes: anationwide population-based study. Am JObstetGynecol 2012;207:288.e1-7

7. Henderson LK, Craig JC, Willis NS, Tovey D,Webster AC. How to write a Cochrane systematicreview. Nephrology (Carlton) 2010;15:617-24.

8. NHS Center for Reviews and Dissemination. Systematic reviews: CRD's guidancefor undertaking reviews in health care. York,United Kingdom: University of York; 2009.
9. Welch V, Petticrew M, Petkovic J, et al.Extending the PRISMA statement to equityfocusedsystematic reviews (PRISMA-E 2012):explanation and elaboration. J Clin Epidemiol2016;70:68-89.

10. MoherD,LiberatiA, TetzlaffJ,AltmanDG;PRISMA Group. Preferred reporting items forsystematic reviews and meta-analyses: thePRISMA statement. Ann Intern Med 2009;151:264-9.

11. Zorzela L, Loke YK, Ioannidis JP, et al.PRISMA harms checklist: improving harmsreporting in systematic reviews. BMJ,2016;352:1157.

12. Stroup DF, Berlin JA, Morton SC, et al. Metaanalysisof observational studies in epidemiology:a proposal for reporting. Meta-analysis of ObservationalStudiesin Epidemiology (MOOSE) Group.JAMA 2000;283:8-12.

13. Murad MH, Sultan S, Haffar S, Bazerbachi F.Methodological quality and synthesis of caseseries and case reports. BMJ Evid Based Med2018;23:60-3.

14. Chen H, Guo J, Wang C, et al. Clinicalcharacteristics and intrauterine verticaltransmission potential of COVID-19 infectionin nine pregnant women: a retrospective reviewof medical records. Lancet 2020;395:809-15.

15. Wang X, Zhou Z, Zhang J, Zhu F, Tang Y,Shen $X$. A case of 2019 novel coronavirus in apregnant woman with preterm delivery [publishedonline ahead of print, ClinInfect Dis 2020. ciaa200.

16. Zhu $\mathrm{H}$, Wang $\mathrm{L}$, Fang $\mathrm{C}$, et al.Clinicalanalysis of 10 neonates born to mothers with2019-nCoV pneumonia. TranslPediatr 2020;9:51-60.

17. Li $\mathrm{Y}$, Zhao $\mathrm{R}$, Zheng $\mathrm{S}$, et al.Lack of verticaltransmission of severe acute respiratory syndromecoronavirus 2, China [published onlineahead of print, Emerg Infect Dis2020;26.

18. Liu $\mathrm{D}, \mathrm{Li} \mathrm{L}, \mathrm{Wu} \mathrm{X}$, et al.Pregnancy andperinatal outcomes of women with COVID-19pneumonia: a preliminary analysis (Feb. 29,2020).

19. Tektook NK, Yadav PR, Alazzawy MA. Prevalence Corona Virus Disease 2019 (COVID-19) in AlFallujah City. International Journal of Advances in Medical Sciences. 2020,5:01-6. 